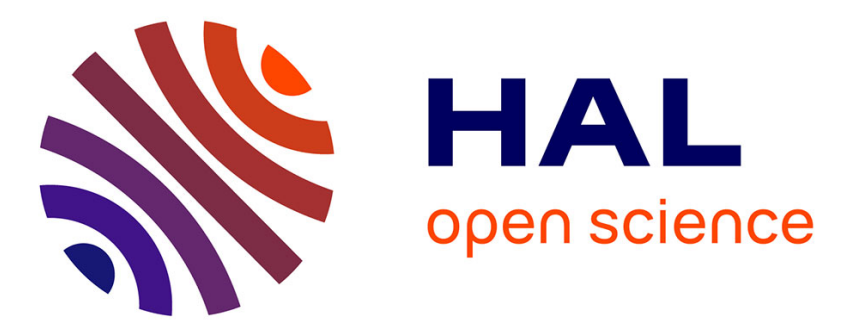

\title{
Using Continuous Turbidity and Seismic Measurements to Unravel Sediment Provenance and Interaction Between Suspended and Bedload Transport in an Alpine Catchment
}

\author{
C Misset, A Recking, C Legout, M Bakker, F Gimbert, T Geay, S Zanker
}

\section{To cite this version:}

C Misset, A Recking, C Legout, M Bakker, F Gimbert, et al.. Using Continuous Turbidity and Seismic Measurements to Unravel Sediment Provenance and Interaction Between Suspended and Bedload Transport in an Alpine Catchment. Geophysical Research Letters, 2021, 48 (4), pp.e2020GL090696. $10.1029 / 2020 \mathrm{gl} 1090696$. hal-03454637

\author{
HAL Id: hal-03454637 \\ https://hal.science/hal-03454637
}

Submitted on 29 Nov 2021

HAL is a multi-disciplinary open access archive for the deposit and dissemination of scientific research documents, whether they are published or not. The documents may come from teaching and research institutions in France or abroad, or from public or private research centers.
L'archive ouverte pluridisciplinaire HAL, est destinée au dépôt et à la diffusion de documents scientifiques de niveau recherche, publiés ou non, émanant des établissements d'enseignement et de recherche français ou étrangers, des laboratoires publics ou privés. 


\section{Geophysical Research Letters}

\author{
RESEARCH LETTER \\ 10.1029/2020GL090696 \\ Key Points: \\ - Combining turbidity and seismic \\ measurements in rivers can be used \\ to identify changes in fine sediment \\ sources: river bed versus hillslopes \\ - River bed mobility and snow \\ cover exert an important control \\ on suspended load in Alpine \\ catchments \\ - Suspended sediment transfer in \\ mountainous environments may \\ shift from river bed to hillslope \\ dominated in a context of global \\ warming
}

Supporting Information:

- Supporting Information S1

Correspondence to:

C. Misset,

clement.misset@gmail.com

Citation:

Misset, C., Recking, A., Legout, C., Bakker, M., Gimbert, F., Geay, T., \& Zanker, S. (2021). Using continuous turbidity and seismic measurements to unravel sediment provenance and interaction between suspended and bedload transport in an Alpine catchment. Geophysical Research Letters, 48, e2020GL090696. https://doi. org/10.1029/2020GL090696

Received 13 SEP 2020 Accepted 21 DEC 2020

(C) 2020. American Geophysical Union. All Rights Reserved.

\section{Using Continuous Turbidity and Seismic Measurements to Unravel Sediment Provenance and Interaction Between Suspended and Bedload Transport in an Alpine Catchment}

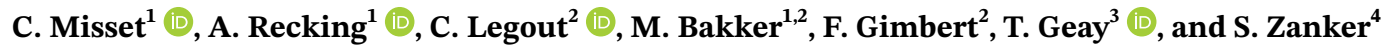 \\ ${ }^{1}$ Univ. Grenoble Alpes, INRAE, ETNA, Grenoble, France, ${ }^{2}$ Univ. Grenoble Alpes, CNRS, IRD, Grenoble INP, IGE, \\ Grenoble, France, ${ }^{3}$ BURGEAP, Grenoble, France, ${ }^{4}$ EDF, DTG, Grenoble, France
}

\begin{abstract}
Fine sediment transport results from the complexity of the interactions between the different modes of transport and the variety of possible sediment sources, from the river bed stocks remobilization to hillslopes erosion. From a 2-year period in an Alpine catchment, we show how the combined use of continuous turbidity and seismic measurements can help to address these issues. In the studied catchment, the signals are more strongly correlated during the high flows of the snowmelt period than during the summer period when the river bed is stable and the hillslopes are no longer protected by a snow cover during storms. This sheds light on the seasonal control exerted by the river bed mobility and the snow cover on suspended sediment dynamics in mountainous catchments. It also questions the potential shift of this dynamics from river bed to hillslope dominated in a context of global warming.
\end{abstract}

Plain Language Summary Suspended sediment transport is a critical process for hydraulic structures and water system management or to understand landscape evolution. Suspension results from complex interactions with the river bed and the variety of possible sediment sources on catchments slopes. These interactions and sources activations are difficult to observe and quantify in the field which partly explain our difficulty to better understand suspended load. From a 2-year period in an Alpine catchment, we show how the combined use of widely available continuous measurements of suspended load (via water turbidity sensor) and river bed mobility (via seismic sensor) can be used to better understand these processes. During high flows of the snowmelt period, both measurements are correlated. On the contrary, a much variable relation is observed during the summer period when the river bed is stable and the hillslopes are no longer protected by a snow cover during storms. These observations shed light on the seasonal control exerted by the river bed mobility and the snow cover on suspended sediment dynamics in mountainous catchments. It also questions the potential shift of this dynamics from river bed to hillslope dominated in a context of global warming.

\section{Introduction}

Studying sediment transport partitioning between bedload and suspended load has been a major research topic for decades (Bagnold, 1966; Einstein et al., 1940; Turowski et al., 2010). This partitioning is crucial for the understanding of sediment transport processes and the transfer of sediment in catchments. Coarse particles (boulders to sand) are often considered to be transported as bedload by sliding, rolling, or saltating and thus strongly interacting with the river bed and its morphology (Ashmore, 1988; Hoey, 1992). Finer particles (sand to clay) are often considered to be transported over longer distances in suspension throughout the water column without necessarily interacting with the bed (Einstein et al., 1940). Due to these long transport distances, the fine fraction generally originates from various sources and processes including rainfall and runoff erosion of nonvegetated hillslopes (Cheraghi et al., 2016; Mohamadi \& Kavian, 2015) or rapid mass movements and debris flows suddenly connecting source areas to the river system (Fryirs, 2013). The fine fraction may also originate directly from the river bed resuspension (Misset, et al., 2019), although the extent to which this fraction interacts with the river bed is often unknown (Walling et al., 1998).

Quantifying this is crucial for the understanding of landscape evolution (Ludwig \& Probst, 1998), river system, and reservoir management planning (Kondolf et al., 2014) or optimizing water resource quality 
strategies (Owens et al., 2005) among others. These applications all strongly benefit from insight in the provenance of suspended sediments and their interaction with the river bed, that is, storage and release of sediment. With ongoing climate change, the contribution of suspended sediment sources might also change dramatically, leading to potentially large changes in water system functioning (Lane et al., 2019). This is particularly true in mountainous environments that experience significant decreases in snow and ice cover due to global warming (Bakker et al., 2018; Comiti et al., 2019) and associated increases of unprotected surface areas that are subject to more frequent rainfall erosion (Costa et al., 2018).

The fundamental question of suspended load origin was addressed in the pioneer work of Einstein et al. (1940) who subdivided the suspended load of the Enoree River (in the United States) depending on its interaction with the river bed. Einstein et al. (1940) were the firsts to introduced "bed-material suspended load" as the fraction of suspended load that strongly interacts with the river bed while "wash load" was used to describe the fraction that has a much weaker interaction with the river bed. This conceptual subdivision has led researchers to make a difference in the way they sought to quantify these processes: "bed-material suspended load" was considered to be controlled by the flow transport capacity while "wash load" was considered to be a function of the sediment availability in the watershed (Partheniades, 1977; Yang \& Simões, 2005). Since the work of Einstein et al. (1940), several criteria have been proposed for suspended material partitioning. These are mostly based on the sediment size fraction absent on the river bed surface (Einstein et al., 1940), a critical particle size (Partheniades, 1977), a critical Rouse number (Wang \& Dittrich, 1992; Wang et al., 2007), a particle size ratio between bed and suspended material, or a balance between transport capacity and sediment availability (Hill et al., 2017). However, in the past decades, flume experiments (Diplas, 1994; Drummond et al., 2017; Hill et al., 2017; Mooneyham \& Strom, 2018) and field observations (Cook et al., 2018; Meunier et al., 2006; Misset, et al., 2019; Misset, Recking, Navratil, et al., 2019; Navratil et al., 2010; Park \& Hunt, 2018) have questioned on the consistency of these thresholds for suspended load partitioning. It therefore remains an open scientific question to which extent suspended load interacts with the river bed (Mathers et al., 2017; Vercruysse et al., 2017).

To quantify the presence or absence of this interaction, it is necessary to continuously and concomitantly measure suspended load and river bed mobility. Although turbidity measurements are widely used to measure the suspended sediment concentration (SSC) (Lewis, 1996; Vercruysse et al., 2017), yet continuous measurements of river bed mobility remain challenging to conduct. A promising technique to do so consists in near river bed passive seismic monitoring. Recent observations and theoretical considerations suggest that river-induced seismic ground motion is largely caused by the transport of coarse particles impacting the river bed (Burtin et al., 2008; Gimbert et al., 2014; Tsai et al., 2012), such that the associated bedload transport flux can be inverted from ground-motion amplitude measurements (Bakker et al., 2020; Dietze et al., 2019; Gimbert et al., 2019; Tsai et al., 2012). More generally, seismic observations may be a particularly relevant proxy for river bed mobility, especially given its strong dependency on the coarsest transported grain sizes (Tsai et al., 2012) whose motion is known to control river bed mobility in gravel bedded streams (MacKenzie et al., 2018; Recking, 2010). Despite such evidence and recent observations of suspension coevolving with seismic ground motion during an extreme flood (Cook et al., 2018), the potential of the combined application of nonintrusive turbidity and seismic measurements remains to be fully investigated.

In the present work, we propose to use such combination to study the temporal dynamics of suspended load-river bed interactions and gain insight in the respective contributions of each suspended particle sources (i.e., river bed vs. hillslopes). These combined measurements, requiring a limited field effort, provide new opportunities to monitor changes in sediment transfer regime in mountain catchments where (i) alluvial river beds exhibit a strong capacity to temporarily store and release fine sediments and (ii) global warming is expected to lead to drastic changes in the sediment transfer regime.

\section{Field Site and Methods}

The Séveraisse catchment is a mesoscale watershed representative of Alpine environments, located in the Ecrin massif in the French Alps (Figure 1). At the monitoring station (red point in Figure 1), the drainage area is $130 \mathrm{~km}^{2}$ and its elevation ranges between 1,027 and 3,579 m NGF (French national reference system). The catchment is characterized by a low human impact and actively eroding hillslopes (Figure 1(a)) 
Monitoring station

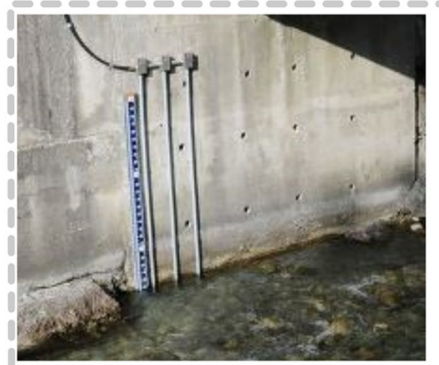

Pressure sensor

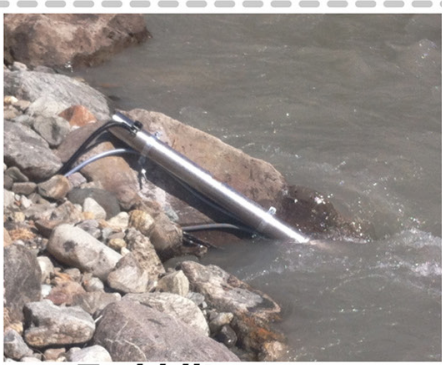

Turbidity sensor

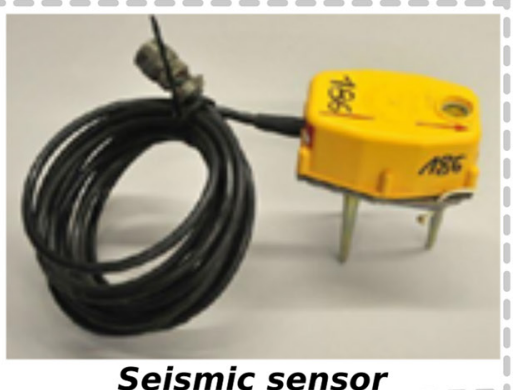

Seismic sensor (a)

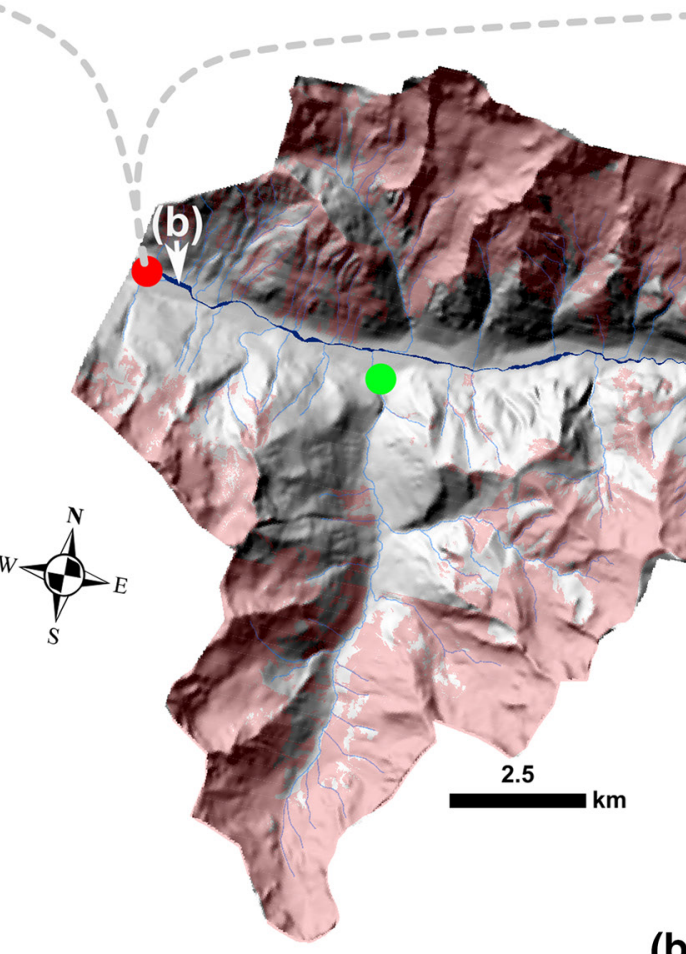

(b)

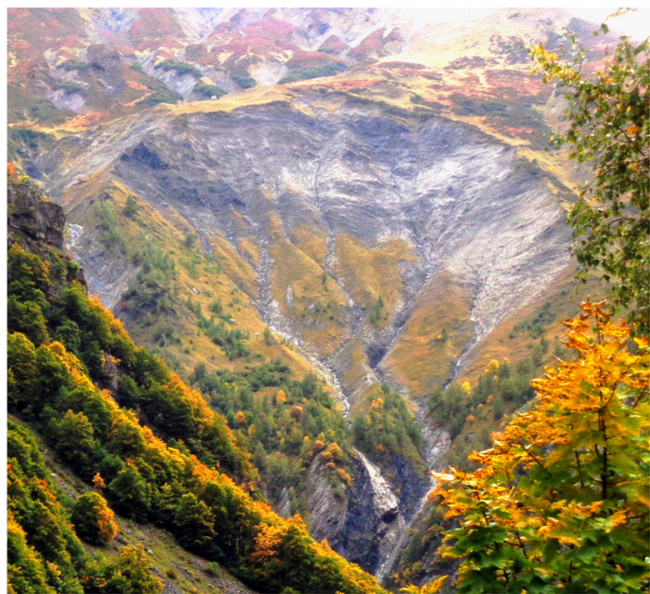

Hillslope sources

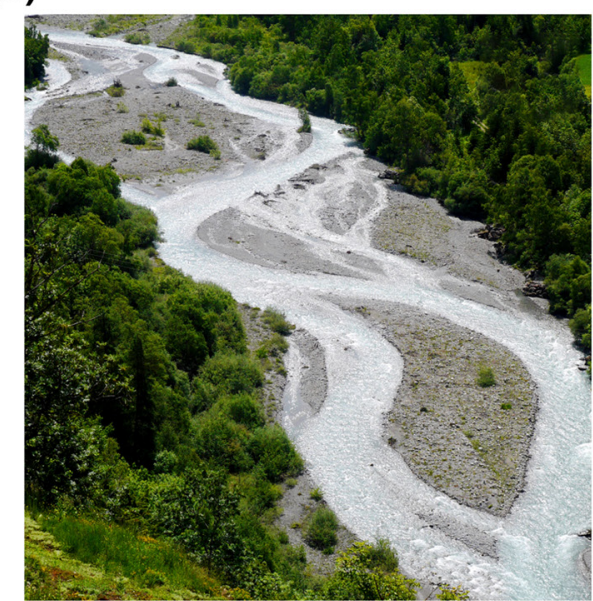

Riverbed sources

Figure 1. Presentation of the field site and the monitoring configuration. 
that supply large quantities of sediment to the valley bottom during debris flow (Helsen et al., 2002) or rock fall events. A significant fraction of the catchment (8\%) is covered by highly erodible surface material that can deliver suspended sediment to the river system during rainfall-runoff events (marls, schists). Other potential hillslope sources of fines are moraines (12\% of the catchment) or alluvium and scree material (23\%). The latter two are mainly connected to the river system by debris flows and small tributaries (see supplementary material S17 for more details on hillslope sources spatial distribution).

The river bed in the downstream part of the valley has a slope between $1 \%$ and $2 \%$ and alternates between braided reaches, with active width of approximatively $100 \mathrm{~m}$ (Figure 1(b)), and narrower, constrained sections of approximately $20 \mathrm{~m}$ wide. The river bed grain size distribution (GSD), obtained from nontruncated Wolman (1954) counts (more than 1,600 particles and performed in May and June 2018) in the two braided sections just upstream of the monitoring station, has a median diameter of $37 \mathrm{~mm}$ and a $84^{\text {th }}$ percentile of $113 \mathrm{~mm}$ (Misset et al., 2020). The fine particles stored as patches at the bed surface have a median diameter range of 104-214 $\mu \mathrm{m}$ (dispersed GSD using a laser diffraction sizer Malvern, Mastersizer 2000 on six randomly chosen samples), while fine particles transported in suspension and sampled at discharges higher than $14 \mathrm{~m}^{3} / \mathrm{s}$ have a median diameter of $188 \mu \mathrm{m}$. The finest fraction of fine sediments stored in the bed matrix (obtained using a resuspension technique detailed in Misset, Recking, Legout, Valsangkar, et al. 2019) was found to have a GSD range similar to surface deposits and sampled suspended particles.

The hydrologic regime of the river is characterized by snowmelt in the late spring to the beginning of summer, and by the ice-melt and storm-events during the late summer and autumn. Low-flow periods are observed when the basin has a snow cover in winter. We conducted measurements from the onset of snowmelt (April) to the onset of snow cover (November) in the years 2018-2019.

We performed measurements at a hydrometric station located in a laterally constrained and paved river section (poorly mobile coarse bed, and nearly vertical banks protected with blocs, red point in Figure 1). This station is operated by EDF (French hydroelectricity company) and provides 1-min average water levels (with a 1-Hz frequency) every 10 min using a pressure sensor. Repeated gauging were performed during the survey period using salt dilution, current meter, or Acoustic Doppler Current Profiler techniques to build a (nonlinear) rating curve between the water level and the flow rate $(\mathrm{Q})$.

A turbidity meter (Hach Lange Solitax) was installed approximately $50 \mathrm{~cm}$ above the bottom of the river bed, near the pressure sensor (Figure 1). This sensor has a detector aligned with an angle to the beam to measure the scattered light. It also has an automatic cleaning system preventing the development of biofilm on the sensor which was regularly verified by the field team. Turbidity values (Tu, FNU) were recorded every $10 \mathrm{~min}$, each of which being obtained by averaging a $1 \mathrm{~min}(1 \mathrm{~Hz})$ continuous measurement. Turbidity is a nonlinear function of SSC and suspended particle size (Landers \& Sturm, 2013; Lewis, 1996). For a given SSC, a decrease in suspended sediment size would lead to an increase of the measured turbidity (Landers \& Sturm, 2013). It is thus most often used in combination with direct sampling and liquid discharge monitoring to estimate the suspended load (Landers \& Sturm, 2013; Lewis, 1996; Mano et al., 2009; Navratil et al., 2011; Orwin \& Smart, 2004). It is worth to note that turbidity measurements are not sensitive to coarse particle transport.

A seismic sensor (PE-6/B geophone) was installed $32 \mathrm{~m}$ from the left channel bank near the turbidity and water pressure sensors (Figure 1). This geophone records ground-motion vibrations in the range about 5-200 Hz including frequencies expected for bedload transport (Bakker et al., 2020; Gimbert et al., 2019; Tsai et al., 2012) and flow turbulence (Gimbert et al., 2014). The data were recorded with a 400-Hz frequency on a DiGOS DATA-CUBE ${ }^{3}$. The seismic signal of vertical ground vibrations $(\mathrm{m} / \mathrm{s})$, obtained after correcting the digital signal (in counts) for geophone response and data logger settings, was analyzed in the time frequency domain as described in Bakker et al. (2020). Spectrograms with a 3s temporal resolution were obtained using the method of Welch (1967) and were aggregated to a 10-min resolution, using a median value to minimize anthropogenic noise. We used the seismic power $\left(\mathrm{P}_{\mathrm{b}}, \mathrm{m}^{2} / \mathrm{s}^{2}\right)$ at a frequency of $50 \mathrm{~Hz}$, providing a maximum sensitivity to bedload transport (Bakker et al., 2020). This frequency range associated with bedload was determined directly by comparing seismic measurements with cross-section bedload samples and indirectly by scaling discharge (Bakker et al., 2020). Seismic power caused by bedload transport $\left(\mathrm{P}_{\mathrm{b}}\right)$ results from impacts exerted by the transported material on the river bed. It is expected to be 


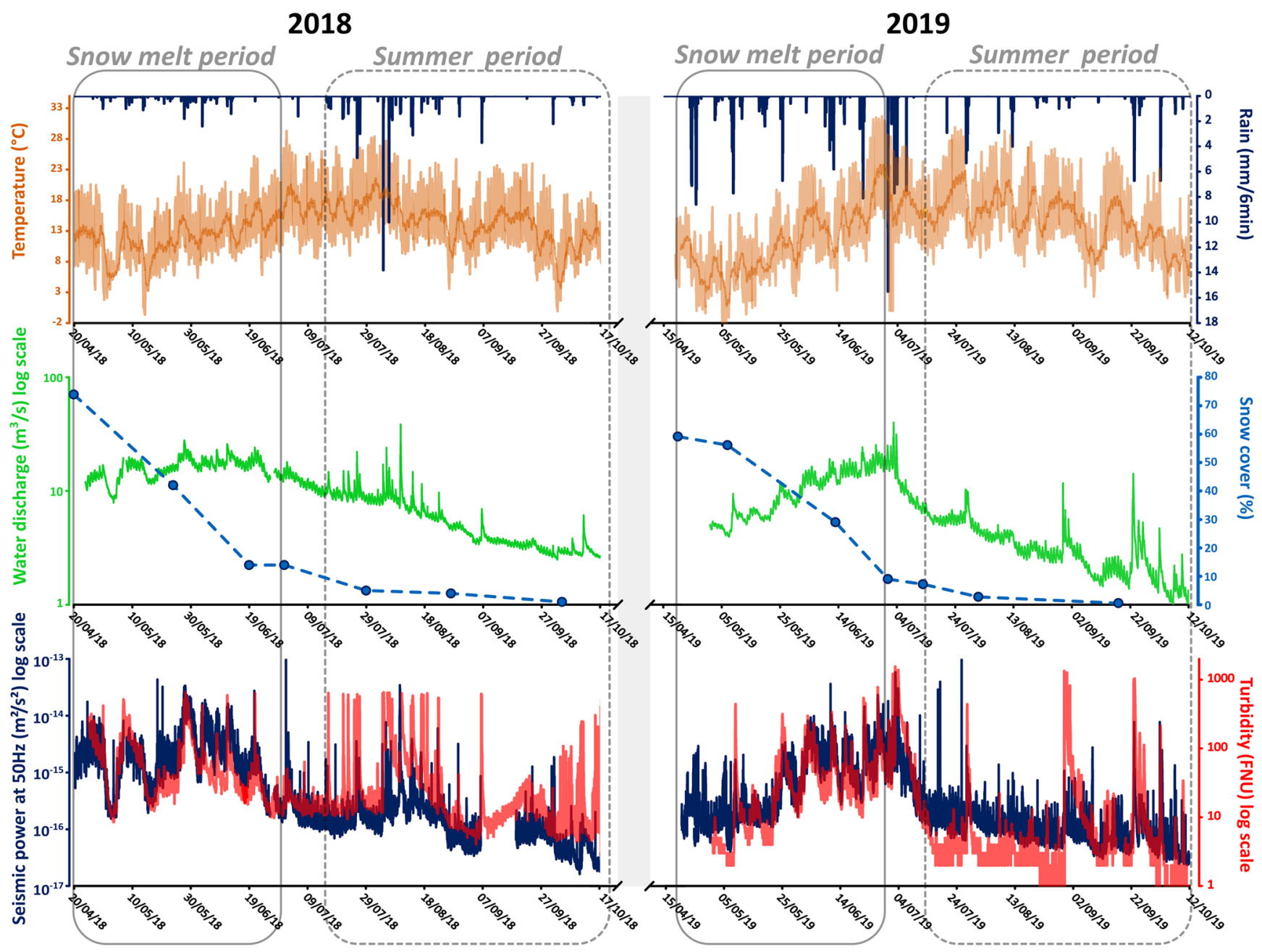

Figure 2. Time series of the measurements conducted in the Séveraisse catchment.

a function of the bedload flux and to scale with the coarsest fraction (approximatively the 95\% percentile of the GSD) of the transported material to a power of approximately 3 (Bakker et al., 2020; Tsai et al., 2012). Because of the large sensitivity of the seismic sensors to the impacts of the coarsest grains, it follows that seismic measurements are not expected to be sensitive to fine particles transported in suspension.

Air temperature and rainfall data were also provided by the EDF company with a temporal resolution of $6 \mathrm{~min}$. These measurements were taken from a meteorological station located approximately $5 \mathrm{~km}$ upstream from the outlet of the catchment (green point in Figure 1). The snow cover of the catchment was determined using satellite images (four-band PlanetScope Scene) with no cloud cover and spread over the monitoring period (seven dates for each year). These images were downloaded from the Planet website (www.planet.com), classified with a semiautomatic algorithm to extract snow areas. Classified images are provided as supplementary material.

\section{Results}

From the data analysis, two periods are identified for both years. The first period is characterized by increasing air temperatures (from 0 to $20^{\circ} \mathrm{C}$ on average), decreasing snow cover (from $70 \%$ to $10 \%$ ) and high flow discharge (higher than $10 \mathrm{~m}^{3} / \mathrm{s}$ on average) (Figure 2). This period takes place during the snowmelt from mid-April to the end of June. The second period is characterized by decreasing air temperatures (from $20^{\circ} \mathrm{C}$ to nearly $0^{\circ} \mathrm{C}$ on average), low snow cover (less than 10\%) and, on average, low-flow discharge (less than 


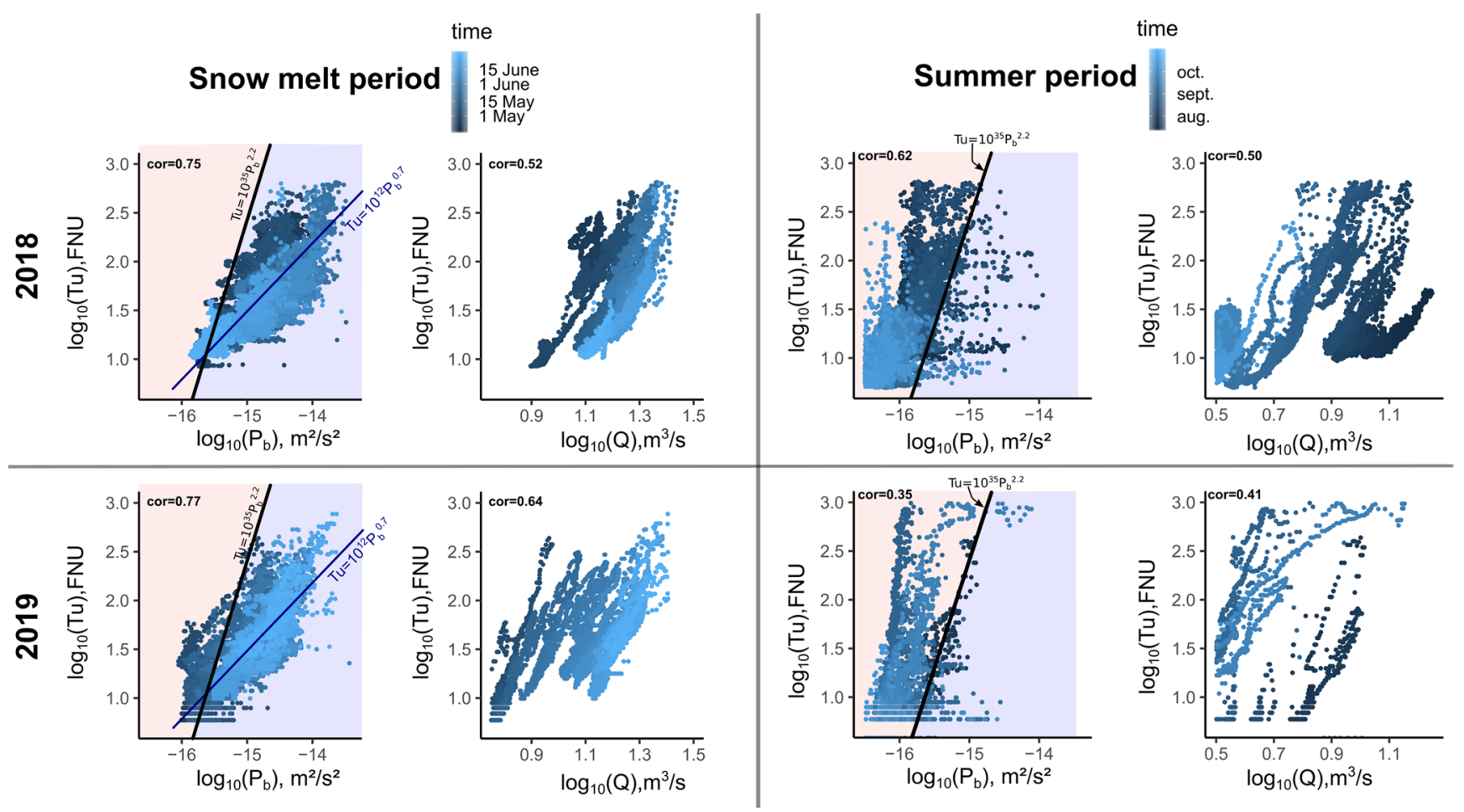

Figure 3. Relations between turbidity (Tu), flow rate (Q), and seismic power at $50 \mathrm{~Hz}\left(\mathrm{P}_{\mathrm{b}}\right)$ during the 2018 and 2019 seasons for both the melting period (Aprillate June) and the summer period (July-October). A partitioning between bed-related suspended load ( $\mathrm{Tu}<10^{35} \mathrm{P}_{\mathrm{b}}^{2.2}$ ) and a hillslope-related suspended load ( $\mathrm{Tu}>10^{35} \mathrm{P}_{\mathrm{b}}{ }^{2.2}$ ) is derived for the Tu- $\mathrm{P}_{\mathrm{b}}$ plots. The blue lines for Tu- $\mathrm{P}_{\mathrm{b}}$ plots during the melting periods correspond to the power law fitted between these two variables considering 2018 and 2019 together. Spearman correlation coefficients are indicated at the top left of each plot. Point color is a function of time.

$10 \mathrm{~m}^{3} / \mathrm{s}$ ). The river hydrology in this second period, from early-July to the end of October, is driven by short events, typically orogenic, convective storms that take place in the summer and autumn.

For the entire measurement period, turbidity varies over 3 orders of magnitude while seismic power varies over nearly 4 orders of magnitude. During the snowmelt period in both years, daily fluctuations are observed in turbidity and seismic power. Also, one can note that both signals are evolving more or less concomitantly. On the contrary, during the July-October period, turbidity and seismic power evolve in a very different way. Short-duration and high-magnitude turbidity events are observed while seismic power remains relatively low. It is clear from this first-order analysis that different sediment regimes are acting during the two different hydrological periods. Using calibration curves presented in previous studies for the melting period (Bakker et al., 2020; Misset, Recking, Legout, Valsangkar, et al., 2019) and assuming these curves are constant through time, we can estimate that the suspended load fraction is on average $67 \%$ during the melting period (72\% for $2018 \%$ and $62 \%$ for 2019 ) and $64 \%$ during the summer period (75\% for $2018 \%$ and $53 \%$ for 2019 , see time series of sediment partitioning in the supplementary information S15). This indicates that both loads are significant in terms of transported volume in the Séveraisse catchment.

A more detailed analysis of the relationships between turbidity $(\mathrm{Tu})$, liquid discharge $(\mathrm{Q})$, and seismic power $\left(\mathrm{P}_{\mathrm{b}}\right)$ for each year and each period is shown in Figure 3. Measurements during the snowmelt period show that the relationship between turbidity and flow rate is highly variable through time. On one hand, Tu-values show a well-marked seasonal variation, with a Tu-Q relationships decreasing from April to June similar to observations in previous studies (Guillon et al., 2018; Mano et al., 2009; Mao \& Carrillo, 2016; Navratil et al., 2011). On the other hand, despite some variability, the relationship between suspended load and bed mobility, inferred through the Tu- $\mathrm{P}_{\mathrm{b}}$ relationship, is much more stable through time. This relationship is similar for 2018 and 2019 and nearly linear in the $\log -\log$ space $\left(\mathrm{Tu} \sim \mathrm{P}_{\mathrm{b}}{ }^{0.7}\right.$, blue line in Figure 3), which is consistent with previous observations by Cook et al. (2018). Consequently, during this period, the seismic signal appears to provide a better means to predict turbidity than the liquid discharge. We obtain 
Mean Temperature $\left({ }^{\circ} \mathrm{C}\right)$

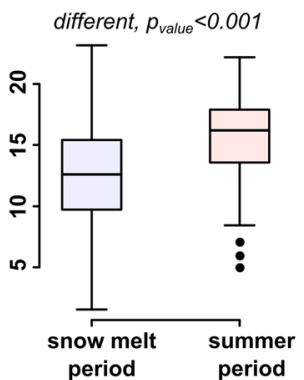

Mean liquide discharge $\left(\mathrm{m}^{3} / \mathrm{s}\right)$

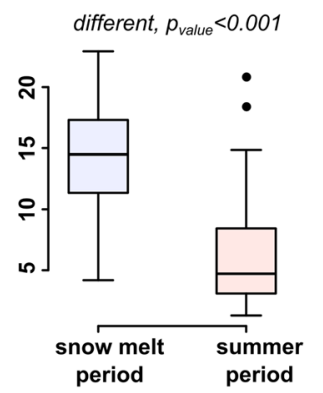

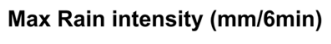

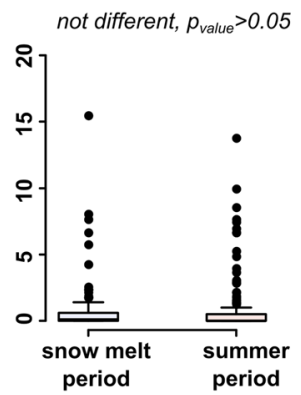

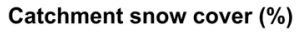

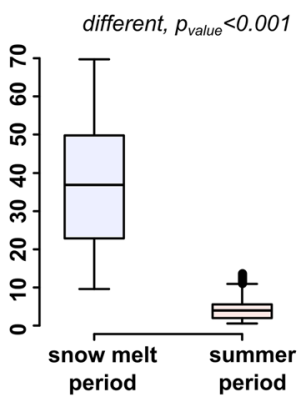

Mean turbidity (FNU)

over

Mean seismic power $\left(10^{15} \mathrm{~m}^{2} / \mathrm{s}^{2}\right)$

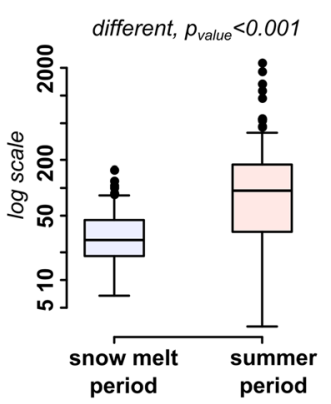

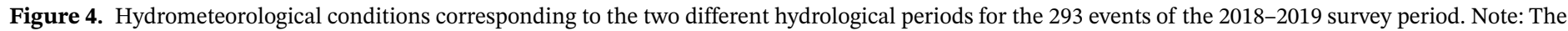

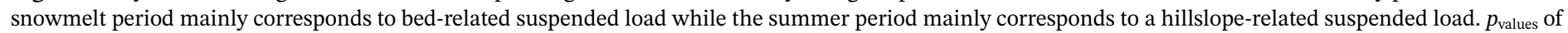
nonparametric Mann-Whitney tests comparing the statistical distributions of both periods are indicated.

spearman correlation coefficients of 0.75 for 2018 and 0.77 for $2019\left(\mathrm{Tu}-\mathrm{P}_{\mathrm{b}}\right)$ and 0.52 for 2018 and 0.64 for 2019 (Tu-Q). In contrast, measurements during the summer storm period show a markedly different behavior. Both the $\mathrm{Tu}-\mathrm{Q}$ and $\mathrm{Tu}-\mathrm{P}_{\mathrm{b}}$ relationships are highly variable through time and weak correlations exist between these signals, with spearman correlation coefficients of 0.62 for 2018 and 0.35 for $2019\left(\mathrm{Tu}-\mathrm{P}_{\mathrm{b}}\right)$ and of 0.5 for 2018 and 0.41 for 2019 (Tu-Q).

These two types of behaviors corresponding to Tu being well correlated with $\mathrm{P}_{\mathrm{b}}$ during snowmelt and weakly correlated with $\mathrm{P}_{\mathrm{b}}$ during summer can be well distinguished in the Tu- $\mathrm{P}_{\mathrm{b}}$ relationship by using the function $\mathrm{Tu}=10^{35} \mathrm{P}_{\mathrm{b}}{ }^{2.2}$ (black line in Figure 3), obtained with a discriminant analysis (mathematical optimization of the separation line between the two groups by using the R-package MASS). On the contrary, it is not possible to split the Tu-Q data with such a simple threshold function. We interpret these two different types of behavior as the result of different processes supplying fine particles to the flow. Tu coevolving with $\mathrm{P}_{\mathrm{b}}$ at high $\mathrm{P}_{\mathrm{b}}$-values $\left(\mathrm{P}_{\mathrm{b}}>10^{-15}\right.$ and $\left.\mathrm{Tu}<10^{35} \mathrm{P}_{\mathrm{b}}^{2.2}\right)$ is consistent with the supply of fine particles being mainly controlled by the river bed, as was demonstrated by Misset, Recking, Legout, Valsangkar, et al. (2019). In contrast, the high variability of Tu when $\mathrm{P}_{\mathrm{b}}$ is low $\left(\mathrm{P}_{\mathrm{b}}<10^{-15}\right.$ and $\left.\mathrm{Tu}>10^{35} \mathrm{P}_{\mathrm{b}}{ }^{2.2}\right)$ is interpreted as the supply of fine particles being mainly controlled by sources distinct from the river bed, which could correspond either to upstream tributaries or to hillslopes. We should stress that because we do not have SSC measurements during the July-October period we cannot conclude whether the higher turbidity for a given seismic power is solely due to a much higher SSC or to a significant decrease in the suspended sediment size. However, both possibilities support the above interpretation of two distinct sediment supply processes controlling fine sediment dynamics during the two periods. Our findings give further support that suspended load partitioning as proposed by Einstein et al. (1940) varies through time in such a system.

To explore the mechanisms behind the identified suspended sediment dynamics, we analyzed the hydrometeorological conditions corresponding to each period for 293 events characterized by a significant peak discharge and selected using an objective automatic procedure detailed in Misset, Recking, Legout, Poirel, et al. (2019). Results indicate that the events in the snowmelt period, which mainly correspond to bed-related suspended load, are characterized by a relatively lower air temperature, a higher average flow rate, a much higher snow cover, and a lower turbidity-seismic ratio (Figure 4). On the contrary, the events in the summer period, which mainly correspond to a hillslope-related suspended load, are characterized by a relatively higher air temperature, a lower average flow rate, a much lower snow cover, and a higher turbidity-seismic ratio. Both periods have similar maximum rain intensity distributions (no statistical differences), but further analysis shows that $75 \%$ of the significant turbidity peaks (i.e., Tu > $500 \mathrm{FNU}$ ) occurred during the summer periods and that these peaks correspond to high rain intensity (see supplementary information S16 for more details). This analysis of the hydrometeorological conditions is consistent with the partitioning into two production mechanisms indicated by turbidity and seismic data. On one hand, river bed production, that is, the release of fine subsurface material due to the surface armor layer disturbance is likely to govern suspension for high flow rates when the catchment slopes are protected by the snow. On the other 
hand, hillslope production is likely to govern the transport of suspended particles when the river bed mobilization is limited and when the slopes are not protected by snow.

\section{Discussion and Conclusion}

This study illustrates the synergy that arises when combining novel seismic measurements and commonly used turbidity measurements. The monitoring approach developed here may be easily applied in remote environments over long time scales, allowing transport interactions between fine and coarse sediments to be efficiently tracked at high temporal resolution. This observation can be used to detect the activation of sediment sources and improve our understanding of sediment transport processes. We further stress that, more than being a bedload flux proxy as commonly considered in the literature (Bakker et al., 2020; Burtin et al., 2011; Tsai et al., 2012), seismic observations are a relevant mean to study the general river bed mobility.

We demonstrate that combined turbidity and seismic measurements allow studying suspended load partitioning between bed-related suspension (bed-material suspended load) and hillslope-related suspension (wash load). Our observations show that the degree of river bed mobility controls the release of fine particles during high flow periods, a mechanism often neglected when studying suspended load while widely accepted when studying bedload transport (Lenzi et al., 1999; Pitlick et al., 2008; Recking, 2013). The observed suspension-gravel bed interactions are consistent with several flume and scarce field results. Previous studies show that fine particles infiltrate in the gravel matrix even for very low Rouse numbers and stay in the subsurface until the surface coarse bed particles are mobilized (Diplas, 1994; Frostick et al., 1984; Krishnappan \& Engel, 2006), so that a relationship between suspended load and bedload is observed in gravel bedded streams (Meunier et al., 2006; Misset, Recking, Legout, Valsangkar, et al., 2019; Misset, Recking, Navratil, et al., 2019; Park \& Hunt, 2017; Turowski et al., 2010). Also, in addition to the strong relationship between turbidity and seismicity, a weak relationship during the summer periods, when most high turbidity peaks occur, provides an indication of the origin of suspended sediment (bed related vs. hillslope related). During convective storms in this period, fine sediment may be rapidly delivered to the river by debris flows (Pavlova et al., 2014) or due to rainfall-runoff processes (erosion of marls and Schists in our case) (Navratil et al., 2012).

Finally, our observations show that the provenance of fine sediment changes concomitantly with the snow cover, suggesting a strong control of snow on suspended load dynamics in Alpine environments, as also suggested in other recent studies (Comiti et al., 2019; Costa et al., 2018). We postulate that, due to a decrease in snow cover area and duration under climate warming, a shift in sediment origin is expected in the near future in such environments, with an increase in fine sediment delivery from hillslopes.

\section{Data Availability Statement}

Data supporting the content of this paper will be available in a Mendeley data repository (http://dx.doi. org/10.17632/nxvhnjmg8j.1). More details can also be obtained by contacting C. Misset or A. Recking.

Acknowledgments

This project was founded by IRSTEA, Eléctricité de France and the ANR SEISMORIV (grant17-CE01-0008). The authors want to thank two anonymous reviewers who greatly contributed to improve this paper by providing helpful reviews of an earlier version of this manuscript and Harihar Rajaram for his excellent editorial work.

\section{References}

Ashmore, P. E. (1988), Bed-load transport in braided gravel-bed stream models, Earth Surface Processes and Landforms, 13(8), 677-695. https://doi.org/10.1002/esp.3290130803

Bagnold. (1966). An approach to the sediment transport problem from general physics. Geological Survey Professional Paper 422 - I.

Bakker, M., Costa, A., Silva, T. A., Stutenbecker, L., Girardclos, S., Loizeau, J. L., et al. (2018). Combined flow abstraction and climate change impacts on an aggrading Alpine River. Water Resources Research, 54, 223-242. https://doi.org/10.1002/2017WR021775

Bakker, M., Gimbert, F., Geay, T., Misset, C., Zanker, S., \& Recking, A. (2020). Field application and validation of a seismic bedload transport model. Journal of Geophysical Research: Earth Surface, 125, e2019JF005416. https://doi.org/10.1029/2019JF005416

Burtin, A., Bollinger, L., Vergne, J., Cattin, R., \& Nabelek, J. L. (2008). Spectral analysis of seismic noise induced by rivers: A new tool to monitor spatiotemporal changes in stream hydrodynamics. Journal of Geophysical Research, 113, B05301. https://doi. org/10.1029/2007JB005034

Burtin, A., Cattin, R., Bollinger, L., Vergne, J., Steer, P., Robert, A., et al. (2011). Towards the hydrologic and bed load monitoring from high-frequency seismic noise in a braided river: The "torrent de St Pierre", French Alps. Journal of Hydrology, 408(1-2), 43-53. https:// doi.org/10.1016/j.jhydrol.2011.07.014

Cheraghi, M., Jomaa, S., Sander, G. C., \& Barry, D. A. (2016). Hysteretic sediment fluxes in rainfall-driven soil erosion: Particle size effects. Water Resources Research, 52, 8613-8629. https://doi.org/10.1002/2016WR019314 
Comiti, F., Mao, L., Penna, D., Dell'Agnese, A., Engel, M., Rathburn, S., \& Cavalli, M. (2019). Glacier melt runoff controls bedload transport in Alpine catchments. Earth and Planetary Science Letters, 520, 77-86. https://doi.org/10.1016/j.epsl.2019.05.031

Cook, K. L., Andermann, C., Gimbert, F., Adhikari, B. R., \& Hovius, N. (2018). Glacial lake outburst floods as drivers of fluvial erosion in the Himalaya. Science, 362(6410), 53-57. https://doi.org/10.1126/science.aat4981

Costa, A., Molnar, P., Stutenbecker, L., Bakker, M., Silva, T. A., Schlunegger, F., et al. (2018). Temperature signal in suspended sediment export from an Alpine catchment. Hydrology and Earth System Sciences, 22(1), 509-528. https://doi.org/10.5194/hess-22-509-2018

Dietze, M., Lagarde, S., Halfi, E., Laronne, J. B., \& Turowski, J. M. (2019). Joint sensing of bedload flux and water depth by seismic data inversion. Water Resources Research, 55, 9892-9904. https://doi.org/10.1029/2019WR026072

Diplas, P. (1994). Modeling of fine and coarse sediment interaction over alternate bars. Journal of Hydrology, 159, 335-351.

Drummond, J. D., Larsen, L. G., González-Pinzón, R., Packman, A. I., \& Harvey, J. W. (2017). Fine particle retention within stream storage areas at base flow and in response to a storm event. Water Resources Research, 53, 5690-5705. https://doi.org/10.1002/2016WR020202

Einstein, H. A., Anderson, A. G., \& Johnson, J. W. (1940). A distinction between bed-load and suspended load in naturals streams. Transactions: American Geophysical Union, 21(2), 628-633. https://doi.org/10.1029/TR021i002p00628

Frostick, L. E., Lucas, P. M., \& Reid, I. (1984). The infiltration of fine matrices into coarse-grained alluvial sediments and its implications for stratigraphical interpretation. Journal of the Geological Society, 141(6), 955-965. https://doi.org/10.1144/gsjgs.141.6.0955

Fryirs, K. (2013). (Dis)Connectivity in catchment sediment cascades: A fresh look at the sediment delivery problem. Earth Surface Processes and Landforms, 38(1), 30-46. https://doi.org/10.1002/esp.3242

Gimbert, F., Fuller, B. M., Lamb, M. P., Tsai, V. C., \& Johnson, J. P. L. (2019). Particle transport mechanics and induced seismic noise in steep flume experiments with accelerometer-embedded tracers. Earth Surface Processes and Landforms, 44(1), 219-241. https://doi. org/10.1002/esp.4495

Gimbert, F., Tsai, V. C., \& Lamb, M. P. (2014). A physical model for seismic noise generation by turbulent flow in rivers. Journal of Geophysical Research: Earth Surface, 119, 2209-2238. https://doi.org/10.1002/2014JF003201

Guillon, H., Mugnier, J.-L., \& Buoncristiani, J.-F. (2018). Proglacial sediment dynamics from daily to seasonal scales in a glaciated Alpine catchment (Bossons glacier, Mont Blanc massif, France). Earth Surface Processes and Landforms, 43(7), 1478-1495. https://doi. org/10.1002/esp.4333

Helsen, M. M., Koop, P. J. M., \& Van Steijn, H. (2002). Magnitude-frequency relationship for debris flows on the fan of the Chalance torrent, Valgaudemar (French Alps). Earth Surface Processes and Landforms, 27(12), 1299-1307. https://doi.org/10.1002/esp.412

Hill, K. M., Gaffney, J., Baumgardner, S., Wilcock, P., \& Paola, C. (2017). Experimental study of the effect of grain sizes in a bimodal mixture on bed slope, bed texture, and the transition to washload. Water Resources Research, 53, 923-941. https://doi.org/10.1002/2016WR019172

Hoey, T. (1992), Temporal variations in bedload transport rates and sediment storage in gravel-bed rivers. Progress in Physical Geography, 16(3), 319-338, https://doi.org/10.1177/030913339201600303

Kondolf, G. M., Gao, Y., Annandale, G. W., Morris, G. L., Jiang, E., Zhang, J., et al. (2014). Sustainable sediment management in reservoirs and regulated rivers: Experiences from five continents. Earth's Future, 2, 256-280. https://doi.org/10.1002/2013EF000184

Krishnappan, B. G., \& Engel, P. (2006). Entrapment of fines in coarse sediment beds, London, UK: Paper presented at River Flow 2006Conference Paper-Ferreira, Alves, Leal \& Cardoso (eds). Taylor \& Francis Group. https://doi.org10.1201/9781439833865.ch85

Landers, M. N., \& Sturm, T. W. (2013). Hysteresis in suspended sediment to turbidity relations due to changing particle size distributions. Water Resources Research, 49, 5487-5500. https://doi.org/10.1002/wrcr.20394

Lane, S. N., Bakker, M., Costa, A., Girardclos, S., Loizeau, J. L., Molnar, P., et al. (2019). Making stratigraphy in the Anthropocene: Climate change impacts and economic conditions controlling the supply of sediment to Lake Geneva. Scientific Reports, 9(1), 8904. https://doi. org/10.1038/s41598-019-44914-9

Lenzi, M. A., D'Agostino, V., \& Billi, P. (1999). Bedload transport in the instrumented catchment of the Rio Cordon Part I: Analysis of bedload records, conditions and threshold of bedload entrainment. Catena, 36(3), 171-190. https://doi.org/10.1016/S0341-8162(99)00016-8

Lewis, J. (1996). Turbidity-controlled suspended sediment sampling for runoff-event load estimation. Water Resources Research, 32(7), 2299-2310.

Ludwig, W., \& Probst, J. L. (1998). River sediment discharge to the oceans; present-day controls and global budgets. American Journal of Science, 298(4), 265-295. https://doi.org/10.2475/ajs.298.4.265

MacKenzie, L. G., Eaton, B. C., \& Church, M. (2018). Breaking from the average: Why large grains matter in gravel-bed streams. Earth Surface Processes and Landforms, 43(15), 3190-3196. https://doi.org/10.1002/esp.4465

Mano, V., Nemery, J., Belleudy, P., \& Poirel, A. (2009). Assessment of suspended sediment transport in four alpine watersheds (France): Influence of the climatic regime. Hydrological Processes, 23(5), 777-792. https://doi.org/10.1002/hyp.7178

Mao, L., \& Carrillo, R. (2016). Temporal dynamics of suspended sediment transport in a glacierized Andean basin. Geomorphology, 287, 116-125. https://doi.org/10.1016/j.geomorph.2016.02.003

Mathers, K. L., Collins, A. L., England, J., Brierley, B., \& Rice, S. P. (2017). The fine sediment conundrum; quantifying, mitigating and managing the issues. River Research and Applications, 33(10), 1509-1514. https://doi.org/10.1002/rra.3228

Meunier, P., Métivier, F., Lajeunesse, E., Mériaux, A. S., \& Faure, J. (2006). Flow pattern and sediment transport in a braided river: The "torrent de St Pierre" (French Alps). Journal of Hydrology, 330(3-4), 496-505. https://doi.org/10.1016/j.jhydrol.2006.04.009

Misset, C., Recking, A., Legout, C., Bakker, M., Bodereau, N., Borgniet, L., et al. (2020). Combining multi-physical measurements to quantify bedload transport and morphodynamics interactions in an Alpine braiding river reach. Geomorphology, 351, 106877. https://doi. org/10.1016/j.geomorph.2019.106877

Misset, C., Recking, A., Legout, C., Poirel, A., Cazilhac, M., Esteves, M., \& Bertrand, M. (2019). An attempt to link suspended load hysteresis patterns and sediment sources configuration in alpine catchments. Journal of Hydrology, 576, 72-84. https://doi.org/10.1016/j. jhydrol.2019.06.039

Misset, C., Recking, A., Legout, C., Valsangkar, N., Bodereau, N., Zanker, S., et al. (2019). The dynamics of suspended sediment in a typical Alpine Alluvial River reach: Insight from a seasonal survey. Water Resources Research, 55, 10918-10934. https://doi. org/10.1029/2019WR025222

Misset, C., Recking, A., Navratil, O., Legout, C., Poirel, A., Cazilhac, M., et al. (2019). Quantifying bed-related suspended load in gravel bed rivers through an analysis of the bedload-suspended load relationship. Earth Surface Processes and Landforms, 44(9), 1722-1733. https://doi.org/10.1002/esp.4606

Mohamadi, M. A., \& Kavian, A. (2015). Effects of rainfall patterns on runoff and soil erosion in field plots. International Soil and Water Conservation Research, 3(4), 273-281. https://doi.org/10.1016/j.iswcr.2015.10.001

Mooneyham, C., \& Strom, K. (2018). Deposition of suspended clay to open and sand-filled framework gravel beds in a laboratory flume. Water Resources Research, 54, 323-344. https://doi.org/10.1002/2017WR020748 
Navratil, O., Esteves, M., Legout, C., Gratiot, N., Nemery, J., Willmore, S., \& Grangeon, T. (2011). Global uncertainty analysis of suspended sediment monitoring using turbidimeter in a small mountainous river catchment. Journal of Hydrology, 398(3-4), 246-259. https://doi. org/10.1016/j.jhydrol.2010.12.025

Navratil, O., Evrard, O., Esteves, M., Legout, C., Ayrault, S., Némery, J., et al. (2012). Temporal variability of suspended sediment sources in an alpine catchment combining river/rainfall monitoring and sediment fingerprinting. Earth Surface Processes and Landforms, 37(8), 828-846. https://doi.org/10.1002/esp.3201

Navratil, O., Legout, C., Gateuille, D., Esteves, M., \& Liebault, F. (2010). Assessment of intermediate fine sediment storage in a braided river reach (southern French Prealps). Hydrological Processes, 24(10), 1318-1332. https://doi.org/10.1002/hyp.7594

Orwin, J. F., \& Smart, C. C. (2004). The evidence for paraglacial sedimentation and its temporal scale in the deglacierizing basin of Small River Glacier, Canada. Geomorphology, 58(1-4), 175-202. https://doi.org/10.1016/j.geomorph.2003.07.005

Owens, P. N., Batalla, R. J., Collins, A. J., Gomez, B., Hicks, D. M., Horowitz, A. J., et al. (2005). Fine-grained sediment in river systems: Environmental significance and management issues. River Research and Applications, 21(7), 693-717. https://doi.org/10.1002/rra.878

Park, J., \& Hunt, J. R. (2017). Coupling fine particle and bedload transport in gravel-bedded streams. Journal of Hydrology, 552, 532-543. https://doi.org/10.1016/j.jhydrol.2017.07.023

Park, J., \& Hunt, J. R. (2018). Modeling fine particle dynamics in gravel-bedded streams: Storage and re-suspension of fine particles. The Science of the Total Environment, 634, 1042-1053. https://doi.org/10.1016/j.scitotenv.2018.04.034

Partheniades, E. (1977). Unified view of wash load and bed material load. Journal of the Hydraulics Division, 103(9), 1037-1057.

Pavlova, I., Jomelli, V., Brunstein, D., Grancher, D., Martin, E., \& Déqué, M. (2014). Debris flow activity related to recent climate conditions in the French Alps: A regional investigation. Geomorphology, 219, 248-259. https://doi.org/10.1016/j.geomorph.2014.04.025

Pitlick, J., Mueller, E. R., Segura, C., Cress, R., \& Torizzo, M. (2008). Relation between flow, surface-layer armoring and sediment transport in gravel-bed rivers. Earth Surface Processes and Landforms, 33(8), 1192-1209. https://doi.org/10.1002/esp.1607

Recking, A. (2010). A comparison between flume and field bed load transport data and consequences for surface-based bed load transport prediction. Water Resources Research, 46, W03518. https://doi.org/10.1029/2009WR008007

Recking, A. (2013). Simple method for calculating reach-averaged bed-load transport. Journal of Hydraulic Engineering, 139, 70-75. https://doi.org/10.1061/(ASCE)HY.1943-7900.0000653

Tsai, V. C., Minchew, B., Lamb, M. P., \& Ampuero, J.-P. (2012). A physical model for seismic noise generation from sediment transport in rivers. Geophysical Research Letters, 39, L02404. https://doi.org/10.1029/2011GL050255

Turowski, J. M., Rickenmann, D., \& Dadson, S. J. (2010). The partitioning of the total sediment load of a river into suspended load and bedload: A review of empirical data. Sedimentology, 57(4), 1126-1146. https://doi.org/10.1111/j.1365-3091.2009.01140.x

Vercruysse, K., Grabowski, R. C., \& Rickson, R. J. (2017). Suspended sediment transport dynamics in rivers: Multi-scale drivers of temporal variation. Earth-Science Reviews, 166, 38-52. https://doi.org/10.1016/j.earscirev.2016.12.016

Walling, D. E., Owens, P. N., \& Leeks, G. J. L. (1998). The role of channel and floodplain storage in the suspended sediment budget of the River Ouse, Yorkshire, UK. Geomorphology, 22, 225-242.

Wang, Z. Y., \& Dittrich, A. (1992). A study on problems in suspended sediment transportation. In Proceedings, 2nd international conference on hydraulics and environmental modeling of coastal (pp. 467-478). Burlington. VT: Estuarine and River Waters, Ashgate.

Wang, Z. Y., Li, Y. T., \& He, Y. P. (2007). Sediment budget of the Yangtze River. Water Resources Research, 43, W04401. https://doi. org/10.1029/2006WR005012

Welch, P. (1967). The use of fast Fourier transform for the estimation of power spectra: A method based on time averaging over short, modified periodograms. IEEE Transactions on Audio and Electroacoustics, 15(2), 70-73. https://doi.org/10.1109/tau.1967.1161901

Wolman, M. G. (1954). A method of sampling coarse river-bed material. Transactions: American Geophysical Union, 35(6), 6. https://doi. org/10.1029/TR035i006p00951

Yang, C. T., \& Simões, F. J. (2005). Wash load and bed-material load transport in the Yellow River. Journal of Hydraulic Engineering, 131(5), 413-418. https://doi.org/10.1061/(ASCE)0733-9429(2005)131:5(413) 